\title{
Subscription rates
}

Subscription rates for volume 48 (2016) of Advances in Applied Probability (AAP) are as follows (post free and online access at http://journals.cambridge.org/apr). For libraries and institutions: US $\$ 344.00$, $£ 222.00$ (online only); US\$378.00, $£ 244.00$ (online \& print). For individuals, US $\$ 130.00, £ 84.00$ (online \& print). The subscription rates for volume 53 (2015) of Journal of Applied Probability, the companion publication, are the same; for individual subscribers that order both journals at the same time, the combined price is discounted by $10 \%$. Please send all subscription renewals and enquiries to: subscriptions_newyork@cambridge.org in the Americas and journals@cambridge.org for the Rest of the World.

\section{Notes for contributors}

A submission to Applied Probability is considered as a submission to either Journal of Applied Probability (JAP) or Advances in Applied Probability (AAP). Longer papers are typically published in AAP, but the assignment of papers between the two journals is made by the Editor-in-Chief on an issue-by-issue basis. Short communications and letters specifically relating to papers appearing in either JAP or AAP are published in JAP.

Papers submitted to the Applied Probability journals are considered on the understanding that they have not been published previously and are not under consideration by another publication. Accepted papers will not be published elsewhere without the written permission of the Trust. Submitted papers should be in English. It is the author's responsibility to ensure an acceptable standard of language, and a paper failing to meet this requirement may go back to the author for rewriting before being sent out for review.

Papers should include: (i) a short abstract of 4-10 lines giving a non-mathematical description of the subject matter and results; (ii) a list of keywords detailing the contents; and (iii) a list of classifications, using the 2010 Mathematics Subject Classification scheme (http://www.ams.org/msc/). Letters to the Editor need not include these. To assist authors in writing papers in the Applied Probability style, they may use the ${ }_{\mathrm{H}} \mathrm{T} \mathrm{E} \mathrm{X}$ class file aptpub.cls, available from http://www.appliedprobability.org/. Use of this class file is not a condition of submission, but will considerably increase the speed at which papers are processed.

Papers should be submitted as portable document format (PDF) files, not exceeding $1 \mathrm{Mb}$, to the email address submissions_japaap@sheffield.ac.uk. All submissions will be acknowledged on receipt.

\section{Copyright}

The copyright of all published papers is vested in the Applied Probability Trust. When a paper is accepted for publication, the Trust asks the authors to assign copyright by signing a form in which the terms of copyright are listed. Failure to do this promptly may delay or prevent publication.

Authorisation to photocopy items for internal or personal use, or the internal or personal use of specific clients, is granted by the Applied Probability Trust for libraries and other users registered with the Copyright Clearance Center (CCC) Transactional Reporting Service, provided that the corresponding processing and royalty fees (see http://www.copyright.com) are paid directly to CCC, 222 Rosewood Drive, Danvers, MA 01923, USA. 0001-8678/16

PRINTED IN THE UK AT BELL AND BAIN LTD

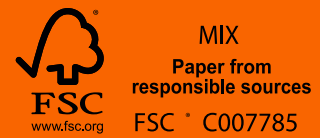




\section{Volume $48 \quad$ Number 1}

1 AMITES SARKAR. Secrecy coverage in two dimensions

13 R. J. MAILLARDET AND P. G. TAYLOR. Queues with advanced reservations: an infinite-server proxy for the bookings diary

32 ERIC FOXALL. Duality and complete convergence for multi-type additive growth models

52 MITSUSHI TAMAKI. Optimal stopping rule for the full-information duration problem with random horizon

69 HOCK PENG CHAN, CHIANG-WEE HENG AND AJAY JASRA. Theory of segmented particle filters

88 FRANCISCO J. SAMANIEGO AND JORGE NAVARRO. On comparing coherent systems with heterogeneous components

112 ZI DING AND ILYA O. RYZHOV. Optimal learning with non-Gaussian rewards

137 ALBERTO GANDOLFI AND LORENZO CECCONI. SIR epidemics on a scale-free spatial nested modular network

163 PANPAN ZHANG AND HOSAM MAHMOUD. The degree profile and weight in Apollonian networks and $k$-trees

176 HANS DADUNA AND RYSZARD SZEKLI. Correlation formulas for Markovian network processes in a random environment

199 WERNER R. W. SCHEINHARDT AND DIRK P. KROESE. A comparison of random walks in dependent random environments

215 ROSS G. PINSKY. The speed of a random walk excited by its recent history

235 G. HUANG, H. M. JANSEN, M. MANDJES, P. SPREIJ AND K. DE TURCK. Markov-modulated Ornstein-Uhlenbeck processes

255 BERND HEIDERGOTT, HARALAMBIE LEAHU, ANDREAS LÖPKER AND GEORG PFLUG. Perturbation analysis of inhomogeneous finite Markov chains

274 HÉLÈNE GUÉRIN AND JEAN-FRANÇOIS RENAUD. Joint distribution of a spectrally negative Lévy process and its occupation time, with step option pricing in view

298 GIORGIO FERRARI AND PAAVO SALMINEN. Irreversible investment under Lévy uncertainty: an equation for the optimal boundary 